\title{
Traumatized Voices in Contemporary Arab-British Women Fiction: A Critical Stylistics Approach
}

\author{
Ahmed Ben Amara ${ }^{1} \&$ Abdulfattah Omar ${ }^{1}$ \\ ${ }^{1}$ Department of English, College of Science and Humanities, Prince Sattam Bin Abdulaziz University, Alkharj, \\ Saudi Arabia \\ Correspondence: Abdulfattah Omar, Department of English, College of Science and Humanities, Prince Sattam \\ Bin Abdulaziz University, Alkharj, Saudi Arabia. E-mail: a.omar@psau.edu.sa
}

Received: April 9, 2018 Accepted: May 2, 2018 Online Published: May 23, 2018

doi:10.5539/ijel.v8n5p117 URL: https://doi.org/10.5539/ijel.v8n5p117

\begin{abstract}
Despite the interest often shown by feminist-informed models of literary trauma in the linguistic properties of traumatized characters' language, very little has been done in relation to the study of the linguistic mechanisms/strategies speakers adopt in narrating traumatic events. This article explores the linguistic and discursive mechanisms in feminist trauma narratives, with a particular focus on the trauma of exile in the diasporic writings of Arab-British women novelists. Given the interdisciplinary nature of the topic, critical stylistics is adopted to describe the hidden discursive mechanisms in the speech of trauma victims, and how these mechanisms affect both the way such unsettling experiences are narrated, and the extent to which the traumatic dimension of these stories is properly conveyed to readers and recipients. Trauma theorists (Caruth 1995, Rogers 2006) have often emphasized the 'unspeakable' nature of traumatic experiences - the way in which they exceed the boundaries of language and expression. Accordingly, our attention should not be directed to what these texts explicitly say. Rather, we should be alert to their silences, gaps, and breaks. In other words, we should be more concerned with how language operates, because it is the cracks and crevices in victims' speech that the full impact of trauma is most likely to be discernible. In the case of Arab-British women writers, traumatic memories of home, the anxiety of exile, and the constant search for identity are all negotiated through language. By adopting such linguistic strategies as repetition and negation, the traumatized characters in the selected texts both point to their in-between subject position, and assert their alternative subjectivity as resistant to clear-cut compartmentalization.
\end{abstract}

Keywords: feminist trauma narratives, diaspora, exile, trauma, critical stylistics, discursive mechanisms

\section{Introduction}

The recent years have witnessed an increasing interest in literary trauma studies, and a number of critics have undertaken the task of re/analyzing a wide range of literary texts using the literary trauma approach (Horvitz, 2000; Kurtz, 2018; Thiemann, 2017). Concerned as it is with the effects of physical and psychological violence, and the means of representing these effects, the discourse of trauma has been particularly attractive to feminist writers. Similarly, feminist literature has often provided rich resources for literary trauma studies. Towards the end of the twentieth century, the representation of literary trauma was the concern of many academics and intellectuals who were interested in feminist literature. Writers and critics such as Christa Wolf, Patricia Grace, Dorothy Allison, Lesile Marmon Silko, Joyce Carol Oates, and Margaret Atwood were particularly interested in the representation of traumatizing experiences of violence and abuse that have traditionally affected women. In their works, they focus on a wide range of personal and collective traumas, including domestic abuse, incest, rape, imprisonment, oppression, and slavery. Today, the relevance of literary trauma theory to feminist literature has become particularly pronounced, in light of the diverse forms of violence that women are increasingly facing in a volatile contemporary situation (Craps, 2013).

In the critical study of the representation of literary trauma in feminist narratives, attention has traditionally been given to the exploration of the ways in which traumatized individuals - usually referred to as 'survivors' or 'victims' - express their experience of psychological trauma through narrative. Emphasis has often been placed on the fact that traumatic experiences are often too painful for traumatized characters to express in ordinary language. In other words, these experiences cannot simply be put into words. In her pioneering study of literary 
trauma theory entitled Unclaimed Experience: Trauma, Narrative, and History, Cathy Caruth (1996) suggests trauma is an unsolvable problem of the unconscious that illuminates the inherent contradictions of experience and language. In other words, trauma is an injury to the psyche that language often fails to adequately represent or express. Concerned as it is with the complexities of representing experiences that defy conventional modes of knowledge and expression, Caruth's approach has been widely used to delineate the recurrent themes of recollected memories of home and the pain of exile that pervade many diasporic feminist narratives (Brown, 2013; Gunne \& Thompson, 2012; Moglen, 2001; Woodiwiss, Smith, \& Lockwood, 2017)

Yet, despite this conceptual awareness of the importance of language in trauma narratives, very little has been done in relation to the study of the linguistic patterns of traumatized characters' speech. As a result, this article explores the linguistic configurations in feminist trauma narratives with a particular focus on the trauma of exile in Arab-British women literature. The rationale behind this is that the feminist narratives of Arab British women writers are generally diasporic in nature, that is to say they are concerned with the problems of imaginative 'home-less-ness' and displacement that female protagonists experience both in their homelands and in diaspora.

In order to do this, critical stylistics, an integrated approach that incorporates both critical discourse analysis and functional approaches to grammar (Jeffries, 2010), is adopted to analyze the representation of the trauma of exile in Fadia Faqir's novel My Name Is Salma and Ahdaf Soueif's collection of short stories Aisha. The rationale behind adopting critical stylistics is that it introduces a set of comprehensive tools that help uncover, explain, and analyze the subconscious thoughts and repressed memories of traumatized characters.

\section{Research Questions}

With the development of literary trauma studies in the second half of the 20th century, a number of women writers have found in the discourse of trauma a universal paradigm for the articulation of women's vulnerable position across cultures and societies. Literary trauma is widely used to represent the psychological trauma of exploitation, violence and abuse that women often face. Feminist writers have been interested in uncovering these and other forms of traumatization and this by means of integrating such experiences of psychological suffering into the feminist discourse. They have also emphasized the impact of social, economic, religious, and political structures on the lives of women in different societies all over the world.

Similarly, in the feminist narratives of Arab-British women writers, literary trauma is used to represent the peculiar predicament of a number of Arab women who have experienced the pain of a problematic sense of belonging and forced exile. The female characters in these narratives are represented as traumatized individuals who have been victimized by social, religious, and political constraints. In her book, Anxiety of Erasure: Trauma, Authorship, and the Diaspora in Arab Women's Writings, Al-Samman (2015) argues that Arab British women writers found in trauma an e

ffective instrument to examine the psychological effects of confinement and exile. She adds that much of ArabBritish women's trauma writing is autobiographical in essence. This is in line with Daphne Grace's (2007) argument that many Arab writers used trauma to express their own suffering and problems. They used storytelling and trauma as an outlet for their repressed feelings. She comments that Arab-British women writers have found in their exile a safe space where they could describe the horrific experiences and accompanying emotions of being themselves victims of violence and injustice in their original Arab societies.

Feminist narratives by Arab-British women writers exhibit a complex body of gendered ideologies as well as social power relations. The peculiar narratives of these Arab women writers raise important questions regarding the limits of existing theoretical structures to deal with subjects whose voice has always been enveloped in silence (Al-Maleh, 2009). They show what it means to be born as a fragile subject in an oppressive environment. It is therefore important to discuss these trauma narratives with in an integrated linguistic theory so as to accommodate the traumatic experiences of a localized group with the broad category of 'victim' that is often evoked by trauma theorists. In this context, this article asks the following research questions. (1) How can the hidden and discursive mechanisms of the painful traumatic experiences in feminist narratives be described and explored linguistically? And how can the linguistic analysis of trauma discourse make women's trauma more visible? (2) What is the impact of the linguistic coordinates and mechanisms which trauma victims use in re/telling their traumatic experiences and stories on highlighting the traumatic effect on readers and recipients?

\section{Methodology}

In order to understand the traumatic experiences of the traumatized characters in the selected texts, this article adopts Jeffries' (2010) critical stylistics approach. Critical stylistics, Jeffries (2014) argues, was developed in reaction to the rise of critical discourse analysis (CDA) as an increasingly influential approach to ideology in 
language. The assumption is that in spite of the widespread applications of CDA in exploring the relationship between language and ideology, stylistics is an indispensable part of any study of ideologies in language. She adds that the tools of stylistic analysis remain at the heart of studying literary and non-literary discourses.

Critical stylistics is an integrated framework that draws together the two methodologies of stylistics and (CDA) in order to uncover the deep ideologies embedded in texts and discourse by means of investigating how these ideologies are conveyed in the language that speakers use. In this way, it provides the missing links between the traditional study of stylistics based on textual choices and CDA that perceives language as a form of social practice. In this sense, it is more comprehensive than both CDA and stylistics. According to Jeffries (2010), critical stylistics adopts a number of structural, lexical, semantic, and pragmatic tools that tend to uncover the hidden ideologies of speakers both in their conscious or unconscious processes. These tools include naming, subordination, information structure, transformation, negating, representing actions, events, and states; presuppositions and implicatures; representing time, space, and society. Jeffries (2010) adds that the function of critical stylistics is to describe how the world is represented and how other's thoughts as well as speeches are constructed in linguistic forms and how these linguistic forms, in turn, are manipulated in order to make the recipients believe, desire, and/or fear.

In our case, critical stylistics is thought to provide new opportunities for understanding the hidden layers of literary texts in relation to social and political aspects as well as stylistic choices. In other words, understanding literary trauma requires a contextualization of the study of literature along with the use of stylistic analysis tools. The idea is that critical stylistics is useful in exploring and describing the painful experiences of female characters in trauma narratives by means of considering the social and political contexts in which texts are produced on the one hand, and the stylistic choices on the other. The tools of critical stylistics are used to investigate the ways in which language is manipulated by authors (in this case Fadia Faqir and Ahdaf Soueif) to communicate their heroines' traumatic experience of exile, as well as their testimonies regarding the injustices inflicted on women.

\section{Analysis}

In her novels, Faqir discusses the traumatic experiences of vulnerable women who face problems of home, exile, belonging, and unbelonging. Her novels often feature stories of troubled Arab Muslim women who experience a sense of being exiled in their own homelands. Even as they gradually adjust to a new life in the West by expressing themselves freely and leading the life they choose, they are still imprisoned by their past. The traumatic experiences of the past and the injustice they faced in their native Arab societies keep intruding on their present and future. Faqir stresses the fact that Arab Muslim women often have a problematic sense of belonging and unbelonging. Gana (2015) indicates that Faqir's novels resist deceptive opposition of literary freedom and Islamic restrictions and limitations, suggesting that the complexities of an Arab-Islamic heritage are often regarded in reductive terms in the Western world.

In an interview with Rachel Bower (2010), Faqir indicates that victims of violence and oppression often resort to fictional writing as a means of expressing psychological trauma. She admits that she herself can find home and refuge in literature and writing. Al-Maleh (2009) comments that Faqir, like many Arab British women writers she calls a tribe of migrant writers, find in writing an outlet to express themselves freely away from the social and cultural restrictions of their native societies. In My Name is Salma, Faqir (2007) narrates the experiences of a young Bedouin girl who is forced by her family to leave her home because she got pregnant out of wedlock. The events of the narrative take place in Britain and are presented in the form of episodic flashbacks, as the main character describes her temporary refuge in prison and her subsequent move to Lebanon before she finally arrives in Exeter to begin a new life there. Obviously, Salma is an outcast: she is not welcome in her own society because of her 'shameful' pregnancy, and is considered a persona non grata.

Salma becomes a symbol of the Arab woman who tries to assert her own identity by confronting the strict norms that consider women as silent, inert, and obedient. For Faqir, this raises the issue of the taboos and strict codes which have long deprived women of their most basic rights, including the right to choose their own paths in life. El-Miniawi (2016) observes that the novel could be read as an autobiographical testimony to the suffering of Arab women in exile. She explains that Faqir creates a new hybrid identity and accepts cultural in-betweenness and double consciousness so as to alleviate the pain of unhomeliness and exile. Salma, in this regard, could be seen as representing Fadia Faqir herself, who has chosen exile in order to escape diverse forms of fundamentalism, dictatorship, and repression in her homeland. She wanted to escape the prison-like environment that made her country of origin or homeland unhomely. In a situation like this, El-Miniawi (2015) argues, a woman finds herself an outsider in her own society, and she accordingly seeks another exile in order to search 
for and assert her own identity.

Fadia Faqir was born in Amman, the capital city of the Hashemite Kingdom of Jordon in 1956 where she completed an undergraduate degree. In 1984 he moved to the UK and there she did an MA and a PhD in creative writing. She now lives in County Durham, England where she works as a teaching fellow in Durham University. The idea that Faqir lived all her childhood and the early part of her adulthood in Jordan is of great significance as it explains the feminist elements of home, exile, and identity in her writings. Faqir left Jordan because of her father who wanted her to be someone she was not: he wanted her to be a pious Muslim, and this made her feel utterly alienated in her homeland. She ultimately found refuge in writing.

During her life in Jordan, El-Miniawi (2015) argues, Faqir felt that she was living in a prison for much of her childhood and her married life. This put her in a clash with her father-whom she thought to be a reluctant tyrant - as well as her community. She was married to a man who was imposed by her father and then got divorced, had a six-year- old child whose custody she lost. She therefore considered herself a failure both as a daughter, wife, and mother. The oppression Faqir experienced as a child and adult in her native society clearly inspired her to depict the lives of marginalized and voiceless Arab women in literature. She often states that though she is Jordanian, she wants to be perceived first and foremost a representative of Arab women who are systematically oppressed within a cruel patriarchal order. Faqir's own experiences as a woman writer born in Jordan before emigrating to and settling in Britain are deeply embedded in her works which give them the immediacy of a memoir.

In writing My name Is Salma, Faqir uses writing as an outlet for the internal conflicts she experienced in her native Arab society. In a later interview with Lindsey Moore (2011), Faqir described her father as a reluctant tyrant. She explained that her father "imposed things on her like praying five times a day, a 7 p.m. curfew... all kinds of things that made me react against institutional religion" (2011, p. 1). She added that the family structure was equally oppressive for women both overtly and covertly: "The family is a structure with a figurehead, a patriarch who makes all the important decisions and treats everyone as infants" (2011, p. 3). In this context, a woman can only suffer in silence; otherwise, she is accused of violating religious and cultural codes - a most unforgivable crime.

In the novel, Salma is threatened to be killed for committing adultery and becoming pregnant out of wedlock. The latter is considered an honor crime, one that violates strict codes of religion and traditions. For her family, the only way to restore family honor is to kill the culprit so that her misdeed is forgotten. However, with the help of some missionary nuns, she is given shelter and finally adopted and shipped away to Britain. In this sad story, we see echoes of Faqir's experiences. Just like the author, Salma is forced to wear the veil and, to make her situation worse, her child is also taken away from her. This shows that that the traumatic experiences of the heroine cannot be entirely separated from the real suffering of the author herself. In many passages, we have the sense that it is the author's voice we hear.

In recalling her troubled past, Salma reveals that she was not allowed in any way to feel or think about the beauty of her body. She was constantly patronized by the patriarchal authority of her father: "Your breasts are like melons, cover them up! my father haj Ibrahim said". Her brother Mahmoud, too, exercised his own brand of patriarchal authority over her, by keeping her constantly under his watch. She was not given any opportunity to live her life in the way she liked:

I looked behind my back to see if I was being watched. If my brother Mahmoud sees me talking to strange men he will tie each leg to a different horse and then get them to run in different directions (Faqir, 2007: 20).

The above citation clearly reflects the extent to which Salma writhed under this oppression. The choice of words such as "strange" and "different" however, reflects the harsh and oppressive nature of the traditions that governed her family and society. This made her feel that she had no identity, and she gradually had to come to terms with the fact that as an Arab Muslim woman, it was her fate to accept a life is dominated by men. This explains her constant struggle in search of an identity. When she meets David at an Exeter cafe, she cannot tell him that she is a Muslim Bedouin Arab woman; instead she chooses to lie about her origins: "I am originally Spanish", she tells him. In so doing, she is trying to be someone else. She knows perfectly well how she will be perceived by her host society if her true identity is revealed. Thus, caught between a painful past and an uncertain future she increasingly becomes suicidal: "If this small glass bottle were full of snake venom I would drink it in one go". Even though she is now safely settled in Britain, she experiences the trauma of exile in the bloom of her youth and this is reflected in the linguistic choice she makes. She is torn between two cultures and their respective languages. She is not able to build grammatically correct English sentences any more than she is 
able to get fully integrated in her new adoptive society. Her struggle to use English correctly reflects her eagerness to be accepted in the new society. However, she is bound to a painful past that continues to haunt her inner peace. She also often finds herself making frequent use of Arabic words in her speech, which clearly shows the extent to which her traumatic past still dominates her life. An example of this is the moment when, in a conversation with Liz, she tries to defend her status in England by saying "I no illegal" meaning "I am not an illegal immigrant". Grammatically speaking, the utterance is just a fragment; it is not a complete sentence. She is not able to use the copula verb am, which shows that she is influenced by the Arabic structure. Her sentence is incomplete just like her incomplete British status. The influence of Arabic grammar and structure in this context is a reflection of the past traumatic experiences that still intrude on her present and future. The use of double negation with no and the prefix il- also reflects her confused state of mind and double consciousness.

The trauma of exile is felt everywhere in the novel. Salma is subject to the merciless conditions of her society. Although her move to England would seem to have saved her from her family's severe punishment, she eventually becomes soulless experiences the confusing loss of identity. In her search for a new identity, she increasingly begins to perceive herself as a "A dark alien" who "has passed through the skies of Exeter". At times, she even doubts whether she deserves to live: "Deserve to die, not live, me, I said and began crying. I also old, no home, no money, no job". The repetition of the negative form 'no' is an indication of her nothingness and lack of self-worth. Interestingly, too, the two sentences, the subject (in the first sentence) and the verb phrase (in the second one) are dropped. The fact that her sentences lack main grammatical constituents to be correct mirrors the lack of a sense belonging that continues to mar Salma's new life.

In exile, Salma cannot forget the unspeakable cruelties inflicted on her at home. Nor can she forget the agony of giving birth to her daughter on that "filthy floor of the prison room" in Islah (meaning Reform) Prison while "alcoholic women, prostitutes, and killers of husbands" watching her.

On the filthy floor of the prison room a bundle of flesh pushed its way out. I shouted, I cried, I begged, then delivered a swollen bundle of flesh, red like beetroot. Alcoholic women, prostitutes and killers of husbands watched while I, the sinner, gave birth on the floor of the Islah prison. Madam Lamaa fixed her pink scarf, wiped her face with both hands and hugged Noura, whose tears were running down her face when she said something that I could not understand. 'Some day you will ... One day you will ...' (Faqir, 2007: 44).

Salma is treated like criminals for having committed adultery. That is why, she describes her newly-born baby as "a swollen bundle of flesh", since normal babies cannot be delivered this way. In the eyes of her society, she is a sinner who deserves no mercy or even life. That is why; there is always something that holds her back in her search of a new identity-her feeling of inferiority due to the way she was brought up. She grew up in a male dominated society where women are oppressed and have almost no rights, a society where all power, privilege, and authorities are exclusively enjoyed by men. It is a society of double standards based on religious and cultural misconceptions.

Another work that explores the traumatizing impact of forced exile on Arab women is Ahdaf Soueif's Aisha (1983), a collection of stories that depict what Edward Said (1983) calls the "depressive tension" between an apparently modern and westernized Egypt, and a set of underlying traditional forms. In Aisha, too, the trauma of exile is a direct result of the problem of double standards in male dominated societies. One example of such double standards, Soueif observes, is the fact that in Arabic, Middle Eastern societies, men are allowed to marry with up to four women. However, it is considered shameful and disgraceful for a woman to even think about something like that. Aisha is, therefore, a cry against women's sense of alienation and exile within their own societies. Soueif suggests that a woman who revolts against the unjust traditional practices of society is made to feel that she is a misfit, and she is deprived of the sense of belonging. Therefore, she finds in writing a means of expressing her feelings and suffering. Writing becomes a tool for resistance, and a space for conciliating the complexities of her hyphenated identities. In her book Atyaf translated under the title of Specters, Ashour (2010) argues that self-expression is perhaps the most significant feature of women's writings. She indicates that among the many forms of self-expression, women find writing, specially novels and autobiography, the most convenient. Writing becomes a process of self-awareness and self-discovery. It presents a sort of memory, and another facet of history that history books, predominantly written by males, would never provide.

Soueif is an Egyptian-English novelist. She was born in Cairo and educated in Egypt and England, where she studied for a Ph.D. at the University of Lancaster. Soueif is not only a writer or novelist. She is also a women's rights activist who has devoted much of her energy and writing to defend woman's cause. Her first collection of short stories entitled Aisha is mainly concerned with Arab women. She discusses her own struggle to carve a place for herself in a male-dominated society. The book is also an example of the injustices done to Arab women 
and the sexual double standards in Arab societies. In these stories, Soueif explores such women-related issues as marginalization, alienation, and diaspora. Although her female characters live in apparently modern and westernized societies, these appearances hide violent and persisting traditional forms.

The first heroine of Soueif's women is Aisha. Aisha's life is many ways similar in to that of Salma. Her story is told in 1964, the first short story in the book. The story is also autobiographical and is based on Soueif's personal life. Like Soueif, Aisha moves to England with her family when she is a teenager. She, too, Aisha's experiences the feelings of alienation, isolation, and discrimination in both Cairo and London. As a teenager in Egypt, she always had the feeling that she did not belong in that culture. She "loved Maggie Maggie Tulliver, Anna Karenina", and "Emma Bovary" as she could understand and relate to them better than the people around her. Her move to England, however, did not provide her with the inner peace she yearned for. Her mother came to England with her traditional way of thinking. Like the majority of Arab and Middle Eastern women, virginity is a matter of supreme importance to her. That is why she keeps asking her daughter whether she had a boyfriend, and whether she kissed him, or sat on his knee. Her classmates, on the other hand, taunted her about her origins and religious background. It is therefore no surprise that her feelings of disappointment and alienation were completed in England.

In 1964 , the trauma of diaspora is clearly reflected in the heroine's linguistic choices. The passive atmosphere is foregrounded in the use of negative adjectives that describe the place and people around her. Her new school is "cold" like everything around her. Her first contact with school was with the "dark" cloakroom lined with "rained-on navy blue" coats, berets and boots. The adjectives convey a sense of gloom, ugliness and lifelessness. It is a colorless life. Accordingly, she "hated" it. This made her persistently feel the need to compare the new school to her old school in Cairo, where she was rather happy and carefree. It also created feelings of agony, bitterness, and distress. Another striking aspect of Aisha's speech is the frequent use of negative forms and structures, which reflects the state of denial she is experiencing. Her responses to her classmates' silly questions and her mother's intervening enquiries are in most cases just "No". The negative expression "No" is very frequently used by the heroine. Aisha's "No" thus becomes a symbol of rejection, refusal, non-existence, and denial. She rejects the ugly face of her new society as it represents alienation, exile, discrimination, marginalization, and homelessness. Aisha's denial could be seen as a form psychological defense against the repeated onslaughts of the pain of exile and up-rootedness. It is also significant that Aisha frequently uses short responses and utterances: "Like what?", "One", "I don't know", and "What?". These laconic responses indicate that she is gradually losing interest in the place and people around her.

In Returning, too, the traumas of exile and alienation have an autobiographical dimension. This short story is considered by different critics to be largely based on the author's own life (Chambers, 2015; D'Alessandro, 2007; Nash, 2007; Said, 1983). In it, the main character feels that she does not belong in her society. She therefore decides to leave country and husband and be free from societal oppression and male indifference. The story reflects many political and social events that drastically changed the face of Egyptian society such as the so-called Islamization movement of the Egyptian society. The story begins with going Aisha back to Egypt as a university teacher after finishing her studies abroad. She realizes that many changes have taken place within her society. She depicts these changes symbolically: "green gardens with spreading trees and flower beds and paths of red sand disappeared, the First Islamic Institute in the Governorate of Giza was established, and many more mosques were built". She suggests that her native country is losing its natural beauty as religious school and the mosque are being built everywhere reflecting the degradation of the environment and the corruption in government institutions. She also notices that more and more women are wearing the hijab which was not as common when she first left Egypt. She feels that this is a new and different society, one that she does not fully know. She believes that the Islamization movement and the degradation of the environment reflect the decline of liberal society and women's rights. She accordingly finds herself in conflict with her own society. What makes it worse is that her relationship with her husband deteriorates. She is not pleased with his enraging indifference and over-inflated egotism. As a reaction, she decides to leave Egypt in order to start a new life somewhere else. Her departure is a symbolic expression of revolt against this 'new' society with its ugliness, indifference, fanaticism, and intolerance.

In The Suitor, Soueif suggests that the problem of double standards is not exclusively related to Islam, but is a deeply rooted cultural marker of Middle East societies. She shows that regardless of their faith, women are destined to occupy a subordinate position. The story is about a Christian girl called Marianne who comes from an upper-middle class family. She is constantly cajoled by her family and a set of importunate suitors. Yet, she is not interested in such traditional forms of marriage, and her rejection of represents a rebellion against a society which that tries to patronize her by intervening even in her choice of a husband. This society becomes almost an 
exile to her. Her mother and uncles are worried about her repeated refusal of marriage proposals, which eventually raises questions about her morals. When she is attracted to an engineer, she is really fascinated by his life style. She likes his Eau Savage, silk robe and Zamalek flat. She sees in him something she has never seen in the suitors introduced by her family. At this point, she believes that she has met the man of her dreams. She surrenders herself completely to him only to find out in the end that he runs a vice ring. She realizes that she has been deceived by his appearances. She is heart-broken and her revolt against the strict codes of her society is ultimately quelled. After this crisis, she gets married to an uninteresting bourgeois who perfectly suits her family's idea of what a good husband should be like. Mariana's final submission to her family and her marriage to a man she is not in love with reflects the triumph of the traditional forms of society.

Marianne's story reflects Soueif's belief that oppression of women through arranged marriages is a social practice that is embedded in Egyptian society. This practice is based on the belief that a woman's life starts after marriage and that once married a woman should be utterly committed to her family. Otherwise, she will bring shame to her family. It becomes clear therefore that the oppression of women is not related to Islam or any religion, but is rather born of social practice.

\section{Conclusion}

This study has found evidence that Trauma theorists often emphasize the importance of the linguistic properties of trauma texts in uncovering the traumatic dimension of certain shocking experiences. Facts from the texts sampled for this study infer that such traumatizing experiences are fundamentally "unspeakable", in other words, they exceed the boundaries of language and expression. This study also reiterated what Cathy Caruth observed that readers' attention should not be directed to what texts explicitly say. Rather, readers should be alert to their silences, gaps, and breaks. Consequently, readers need to be more concerned with how language operates, because it introduces to them the cracks and crevices of victims' speech through which the full impact of trauma is likely to be visible. Another observation of this study was that Arab-British women writers grope with the traumatic memories of home, the problem of exile, and the constant search for identity - all negotiated through language. Finally, as revealed from the texts under study, and by adopting linguistic strategies like repetition and negation, it is also discovered that the traumatized characters both point to their in-between subject position, as well as assert their alternative subjectivity as resistant to clear-cut compartmentalization. This also suggests an overplay of linguistic coordinates used to narrate their traumatic experiences.

The implications of the study range from boundaries of linguistic coordinates to depiction of literary trauma in Arab British Feminist writings. First and foremost this study has observed a few linguistic patterns in trauma narratives that are diasporic in nature. This has revealed the hidden discursive patterns of trauma in this literary genre. The findings have also introduced new avenues of linguistic paradigms that readers could adopt to understand a literary narrative. This would also add a new dimension to the textual interpretation methods adopted in teaching stylistics. The application of such linguistic patterns in trauma feminist diasporic narratives has also never been attempted before which offers it a uniqueness. Another implication of this study deals with the literary trauma of the Feminist writers who not only depict violent experiences of their characters but also integrate their psychological conditions that build up the trauma. The feminist writings so far have discussed issues like crime against women and psychological trauma that results out of it, but this study offers a new kind of literary interpretation, that of representing the literary trauma, in addition to the psychological trauma that has usually been discussed in this kind of writing. Such implications will prove a good contribution to the literary domain of Feminist studies and shall also highlights the diasporic nature of a feminist discourse, which so far was patterned only around male exploitation and description of rapes, sexual assault and other crimes. Its association with literary trauma has been the core element of this study.

\section{Acknowledgments}

This project was supported by the Deanship of Scientific Research at Prince Sattam Bin Abdulaziz University under the research project 7543/02/2017.

\section{References}

Al-Maleh, L. (2009). Arab Voices in Diaspora: Critical Perspectives on Anglophone Arab Literature. Amsterdam: Rodopi.

Al-Samman, H. (2015). Anxiety of Erasure: Trauma, Authorship, and the Diaspora in Arab Women's Writings. Syracuse University Press.

Ashour, R. (2010). Specters. Massachusetts: Interlink Pub Group.

Bower, R. (2010). Interview with Fadia Faqir. Journal of Postcolonial Writing, 48(1), 3-12. 
https://doi.org/10.1080/17449855.2011.569380

Brown, C. (2013). Women's Narratives of Trauma: (Re)storying Uncertainty, Minimization and Self-Blame. Narrative Works: Issues, Investigations \& Interventions, 3(1).

Caruth, C. (1996). Unclaimed Experience: Trauma, Narrative, and History. Baltimore, Md.; London: Johns Hopkins University Press.

Chambers, C. (2015). Britain Through Muslim Eyes: Literary Representations, 1780-1988. Springer. https://doi.org/10.1057/9781137315311

Craps, S. (2013). Postcolonial Witnessing: Trauma Out of Bounds. London: Palgrave Macmillan. https://doi.org/10.1057/9781137292117

D'Alessandro, S. (2007). The Stratheden and the negotiation of the East-West trajectory: identity and migration in Ahdaf Soueif's Aisha. In Prospero (Ed.), Rivista di Letterature Straniere, Comparatistica e Studi Culturali (Vol. XIV pp. 325-333). EUT Edizioni Università di Trieste.

El-Miniawi, N. (2015). Cross cultural communication in my name is Salma, "My name is Salma-By Fadia Faqir". Global Science Research Journals, 3(1), 61-63.

El-Miniawi, N. (2016). The Crisis of Identity in "My Name is Salma". Fikr Wa Ibda', 17(3), 33-55.

Faqir, F. (2007). My Name Is Salma. London: Doubleday.

Gana, N. (2015). Edinburgh Companion to the Arab Novel in English. Edinburgh: Edinburgh University Press.

Grace, D. (2007). Arab Women Write the Trauma of Imprisonment and Exile. In N. A. H. Golley (Ed.), Arab Women's Lives Retold: Exploring Identity through Writing. Syracuse University Press.

Gunne, S., \& Thompson, Z. B. (2012). Feminism, Literature and Rape Narratives: Violence and Violation. London; New York: Routledge.

Horvitz, D. M. (2000). Literary Trauma: Sadism, Memory, and Sexual Violence in American Women's Fiction. SUNY Press.

Jeffries, L. (2010). Critical Stylistics: The Power of English.

Jeffries, L. (2014). Critical Stylistics. In M. Burke (Ed.), The Routledge Handbook of Stylistics. Routledge.

Kurtz, R. (2018). Trauma and Literature. Cambridge: Cambridge University Press. https://doi.org/10.1017/9781316817155

Moglen, H. (2001). The Traum of Gender: A feminist Theory of the English Novel. California: University of California Press.

Moore, L. (2011). "You Arrive at a Truth, Not the Truth": An Interview with Fadia Faqir. Postcolonial Text, $6(2), 1-13$.

Nash, G. (2007). The Anglo-Arab Encounter: Fiction and Autobiography by Arab Writers in English. Peter Lang. https://doi.org/10.3726/978-3-0353-0419-0

Said, E. (1983). Edward Said writes about a new literature of the Arab world. London Review of Books, 5(12), 8.

Soueif, A. (1983). Aisha. London: Jonathan Cape.

Thiemann, A. (2017). Rewriting the American Soul: Trauma, Neuroscience and the Contemporary Literary Imagination. London; New York: Routledge.

Woodiwiss, J., Smith, K., \& Lockwood, K. (2017). Feminist Narrative Research: Opportunities and Challenges: Springer. https://doi.org/10.1057/978-1-137-48568-7

\section{Copyrights}

Copyright for this article is retained by the author, with first publication rights granted to the journal.

This is an open-access article distributed under the terms and conditions of the Creative Commons Attribution license (http://creativecommons.org/licenses/by/4.0/). 